\title{
Regulation of inhibin $\beta$ B-subunit mRNA expression in rat Sertoli cells: consequences for the production of bioactive and immunoreactive inhibin
}

\author{
Ingrid A. Klaij, Marianna A. Timmerman, Leen J. Blok, J. Anton Grootegoed \\ and Frank H. de Jong \\ Department of Endocrinology and Reproduction, Medical Faculty, Erasmus University Rotterdam, Rotterdam, Netherlands
}

(Received 27 December 1991; accepted 21 February 1992)

Key words: Pro- $\alpha$ C; Protein kinase C; Phorbol ester; Calcium ionophore

\section{Summary}

In Sertoli cells from 21-day-old rats, the expression of the mRNA encoding the $\alpha$-subunit of inhibin, and the production of immunoreactive inhibin are stimulated by follicle-stimulating hormone (FSH). In contrast, the amount of $\beta$ B-subunit mRNA is not increased after FSH treatment of the cells, and the ratio between bioactive and immunoactive inhibin decreases after stimulation with FSH. These data suggest that the $\beta \mathrm{B}$-subunit is the limiting factor in the production of bioactive inhibin. The aim of the present experiments was to investigate the effect of changes in the amount of $\beta$ B-subunit mRNA on the production of bioactive and immunoreactive inhibin.

During early postnatal testicular development, the relative amounts of the $4.2 \mathrm{~kb}$ and $3.5 \mathrm{~kb}$ mRNAs encoding the $\beta$ B-subunit of inhibin changed markedly. The meaning of this changing ratio between $\beta B$-subunit mRNAs is not clear, since both mRNAs are actively translated, as demonstrated by polysomal analysis. The total amount of $\beta \mathrm{B}$-subunit mRNA correlated with the in vitro production of bioactive inhibin as published earlier.

Prolonged stimulation of cultured Sertoli cells from 14-day-old rats with $4 \beta$-phorbol 12-myristate 13-acetate (PMA) caused a decreased expression of the $\beta$ B-subunit mRNAs, presumably by down-regulation of protein kinase C. A similar effect was obtained after addition of the calcium ionophore A23187. Concomitantly, a decreased production of bioactive inhibin was observed. Furthermore, Western blotting revealed that secretion of the $32 \mathrm{kDa}$ inhibin $\alpha \beta$-dimer was decreased, whereas secretion of the combination of the C-terminal part with the pro-region of the $\alpha$-subunit was increased.

It is concluded that the level of the $\beta \mathrm{B}$-subunit of inhibin is rate-limiting for the production of bioactive inhibin in cultured Sertoli cells, and that its expression can be influenced by modulation of protein kinase $\mathrm{C}$, and/or intracellular calcium levels.

\section{Introduction}

In the testis, Sertoli cells produce the dimeric glycoprotein inhibin, which can suppress the pro-

Correspondence to: I.A. Klaij, Department of Endocrinology and Reproduction, Erasmus University Rotterdam, P.O. Box 1738, 3000 DR Rotterdam, Netherlands. duction of follicle-stimulating hormone (FSH) by the pituitary gland. One known regulator of inhibin production by Sertoli cells is FSH, as was demonstrated by the observation that the production of immunoreactive inhibin by cultured Sertoli cells could be stimulated by FSH (Bicsak et al., 1987). However, only the expression of the mRNA encoding the $\alpha$-subunit of inhibin was 
stimulated by FSH, presumably through an increase of cAMP, whereas the expression of the $\beta$ B-subunit mRNAs was not affected by FSH or dbcAMP (Toebosch et al., 1988; Klaij et al., 1990). Furthermore, testicular $\beta B$-subunit mRNA levels were not changed significantly in hypophysectomized rats (Krummen et al., 1989), whereas the $\alpha$-subunit mRNA level in the testes of these animals was decreased and could be restored to normal by injection of FSH (Krummen et al., 1989; Keinan et al., 1989).

When proteins from Sertoli cell conditioned medium were separated by sodium dodecyl sulfate-polyacrylamide gel electrophoresis (SDSPAGE), it was shown that the secretion of bioactive inhibin was not increased significantly by FSH (Grootenhuis et al., 1990). Other authors found, possibly depending on the Sertoli cell culture system used, a stimulation of bioactive inhibin of 1.5-fold (Toebosch et al., 1988) to 2-fold (Handelsman et al., 1989).

In contrast, in all studies the inhibin immunoreactivity was elevated dramatically after stimulation with FSH (Bicsak et al., 1987; Toebosch et al., 1988; Risbridger et al., 1989b; Grootenhuis et al., 1990), and thus the ratio between inhibin bioactivity and immunoreactivity was decreased under these conditions. These observations suggest that the expression of the $\beta \mathrm{B}$ subunit gene may be limiting for the production of bioactive inhibin. Therefore, in the present study it was investigated whether a change in the expression of the inhibin $\beta \mathrm{B}$-subunit mRNAs can affect the bioactivity and molecular species of the secreted inhibin and inhibin related proteins. Furthermore, we studied the polysomal distribution of the inhibin subunit mRNAs in order to ascertain if only one, or both, of the $\beta$ B-subunit mRNAs are translated in Sertoli cells.

\section{Materials and methods}

\section{Materials \\ 4 $\beta$-Phorbol 12-myristate 13-acetate (PMA), was from Sigma (St. Louis, MO, USA). The cal- cium ionophore A23187 (A23187) was obtained from Boehringer (Mannheim, Germany). Stau- rosporine was purchased from Serva Feinbio- chemica (Heidelberg, Germany).}

\section{Sertoli cell culture}

Sertoli cell preparations were isolated from testes of 14-day-old Wistar rats essentially as described by Themmen et al. (1991). In short, 48 decapsulated testes were incubated for $20 \mathrm{~min}$ in a shaking water bath at $37^{\circ} \mathrm{C}$ in $20 \mathrm{ml}$ phosphatebuffered saline (PBS), containing DNase 1 (5 $\mu \mathrm{g} / \mathrm{ml}$; DN25, Sigma), collagenase (1 mg/ml; CLS, Worthington, Freehold, NJ, USA), trypsin ( $1 \mathrm{mg} / \mathrm{ml}$; TRL, Worthington) and hyaluronidase (1 $\mathrm{mg} / \mathrm{ml}$; I-S, Sigma). After four successive washes by sedimentation at unit gravity in $40 \mathrm{ml}$ PBS/DNase, the tubular fragments were incubated in $20 \mathrm{ml}$ PBS/DNAse containing $1 \mathrm{mg} / \mathrm{ml}$ collagenase and $1 \mathrm{mg} / \mathrm{ml}$ hyaluronidase. The fragments were washed 4 times, and dispersed using a Dounce homogenizer (ten strokes). The cells were then washed 4 times with PBS/DNase, and once with Eagle's minimal essential medium (MEM; Gibco, Grand Island, NY, USA) by sedimentation at $100 \times g$ for $2 \mathrm{~min}$.

The resulting cell preparation was plated in $150 \mathrm{~cm}^{2}$ culture flasks (Costar, Cambridge, UK) at a density of $25-30 \mu \mathrm{g}$ protein $/ \mathrm{cm}^{2}$, and cultured in MEM supplemented with non-essential amino acids, glutamine, antibiotics, and $1 \%$ fetal calf serum (FCS), at $37^{\circ} \mathrm{C}$ under an atmosphere of $5 \% \mathrm{CO}_{2}$ in air. After $48 \mathrm{~h}$ of culture the cells were shocked hypotonically for $2.5 \mathrm{~min}$ in $0.1 \times$ MEM to remove spermatogenic cells (Galdieri et al., 1981; Toebosch et al., 1988). The culture was continued for $24 \mathrm{~h}$ in MEM without FCS. Subsequently the cells were washed once with MEM, and incubated as described in the Results section.

\section{$R N A$ isolation and analysis}

After removal of the culture medium, cultured Sertoli cells were frozen on solid $\mathrm{CO}_{2}$ /ethanol, and stored at $-80^{\circ} \mathrm{C}$. Testes of rats of various ages were snap-frozen in liquid nitrogen, and stored at $-80^{\circ} \mathrm{C}$. Total RNA was isolated using an acid guanidinium thiocyanate/phenol/chloroform extraction procedure as described by Chomczynski and Sacchi (1987). Of each sample, $40 \mu \mathrm{g}$ of total RNA was denatured in formamide/formaldehyde at $55^{\circ} \mathrm{C}$ for $15 \mathrm{~min}$, prior to electrophoresis on denaturing $1 \%$ agarose/formaldehyde gels. After electrophoresis, RNA was blotted on Hybond $\mathrm{N}^{+}$(Amersham, Bucking- 
hamshire, UK) by diffusion. Filters were baked for $2 \mathrm{~h}$ at $80^{\circ} \mathrm{C}$, and subsequently prehybridized for $2 \mathrm{~h}$ at $42^{\circ} \mathrm{C}$ in a hybridization solution containing $50 \%$ formamide, $9 \% \mathrm{w} / \mathrm{v}$ dextran sulfate, $10 \times$ Denhardt's $(1 \times$ Denhardt's contains $0.02 \%$ $\mathrm{w} / \mathrm{v}$ Ficoll, $0.02 \% \mathrm{w} / \mathrm{v}$ polyvinyl pyrrolidone, $0.02 \% \mathrm{w} / \mathrm{v}$ bovine serum albumin (BSA)), $5 \times$ SSC $(1 \times$ SSC contains $0.15 \mathrm{M} \mathrm{NaCl}, 0.015 \mathrm{M}$ sodium citrate, $\mathrm{pH} 7.0$ ), $10 \mathrm{mM}$ sodium phosphate ( $\mathrm{pH} 6.8$ ), and $100 \mu \mathrm{g} / \mathrm{ml}$ denatured salmon sperm DNA.

Probes for hybridization were labeled with ${ }^{32} \mathrm{P}$ by random oligonucleotide labeling (Feinberg and Vogelstein, 1983), denatured in boiling water for 5 min and added directly to the hybridization solution. Following $48 \mathrm{~h}$ of hybridization at $42^{\circ} \mathrm{C}$ the filters were washed to a final stringency of $0.1 \times \mathrm{SSC}, 0.1 \% \mathrm{SDS}, 50^{\circ} \mathrm{C}$. Amersham Hyperfilm-MP was exposed to the filters at $-70^{\circ} \mathrm{C}$ for various lengths of time, using an intensifying screen.

Intensity of bands was measured by densitometric scanning as described previously (Klaij et al., 1990); the presence of equal amounts of RNA was confirmed by staining of the gel with ethidium bromide. When RNA from cultured Sertoli cells was analyzed, values were normalized against values obtained by hybridization with a $1 \mathrm{~kb}$ hamster $\beta$-actin cDNA probe as an internal standard.

The cDNA probes used were a $1.25 \mathrm{~kb}$ Eco RI fragment encoding the $\alpha$-subunit ( $\alpha 7 / \mathrm{pUC} 18)$, and a $1.5 \mathrm{~kb} E c o$ RI fragment encoding part of the $\beta$ B-subunit $(\beta \mathrm{B} 11 / \mathrm{pUC18})$ of rat inhibin (Esch et al., 1987).

\section{Analysis of polysomal distribution of inhibin mRNAs}

Methods used were essentially as described by Kew et al. (1989). Testes were homogenized at $4^{\circ} \mathrm{C}$ in $1 \mathrm{ml} \mathrm{HKM}$ buffer (20 mM Hepes, $100 \mathrm{mM}$ $\mathrm{KCl}, 20 \mathrm{mM} \mathrm{MgCl}_{2}$ ) containing $0.5 \%$ Triton $\mathrm{X}$ 100, $3 \mathrm{mM} \beta$-mercaptoethanol, $300 \mathrm{U} / \mathrm{ml}$ RNase-inhibitor (RNAsin, Promega, Madison, WI, USA), and $10 \mathrm{mM}$ EGTA to inhibit RNases. After centrifugation for $15 \mathrm{~min}$ at $10,000 \times \mathrm{g}$ to pellet nuclei, supernatants were applied on to a linear gradient of $10-50 \%(\mathrm{w} / \mathrm{v})$ sucrose in HKM buffer. Gradients were centrifuged in a Beckman $\mathrm{SW}-40$ rotor for $2 \mathrm{~h}$ at $36,000 \mathrm{rpm}$. To determine non-specific association of transcripts with polysomal fractions, postnuclear supernatants were also prepared and separated using buffers in which $\mathrm{MgCl}_{2}$ was replaced with $10 \mathrm{mM}$ EDTA (HKE buffer). After centrifugation, gradients were collected in fractions of $1.5 \mathrm{ml}$. RNA in these fractions was precipitated by addition of 1 vol. iso-propanol. Precipitates were resuspended in $0.1 \%$ SDS $/ 10 \mathrm{mM}$ Tris (pH 7.5)/1 mM EDTA, and extracted twice with phenol and once with chloroform. Finally each fraction was ethanolprecipitated, and dissolved in water. Equivalent percentages of total RNA from each fraction were then denatured and electrophoresed as described above.

\section{Analysis of inhibin forms}

Media of Sertoli cell cultures were collected after $24 \mathrm{~h}$ of incubation. The samples were concentrated, using disposable cartridges with YM10 membranes (molecular weight cut-off at $10 \mathrm{kDa}$; Centriprep 10; Amicon, Lexington, MA, USA), and proteins were separated on $15 \%, 0.75 \mathrm{~mm}$ thick SDS-polyacrylamide gels as described by Laemmli (1970) using the Mini-Protean II system (BioRad, Richmond, CA, USA). Subsequently the separated proteins were blotted, using the same system, onto Problott (Applied Biosystems, Foster City, CA, USA) at $100 \mathrm{~V}$ in $1 \mathrm{~h}$. Immunostaining was performed as described by van Laar et al. (1989), using an antiserum directed against the 22 $\mathrm{N}$-terminal amino acid residues of the $\alpha \mathrm{C}$-subunit of $32 \mathrm{kDa}$ bovine inhibin (Grootenhuis et al., 1989), or an antibody against the 20 C-terminal amino acid residues of the pro-part of the rat inhibin $\alpha$-subunit precursor (de Winter et al., 1992).

\section{Inhibin bioassay}

Inhibin bioactivity was determined in an in vitro bioassay, in which suppression of spontaneous FSH release from cultured rat pituitary cells was estimated (Grootenhuis et al,, 1989). Before measurement, $0.01 \%$ BSA was added to the Sertoli cell culture media, which were subsequently exchanged and concentrated, using Cen- 
triprep 10 membranes, in order to remove PMA, A23187, or staurosporine, since these substances affect gonadotropin secretion by pituitary cells. In control experiments with media to which these agents had been added, it was shown that concentrated media did not change FSH secretion.

Charcoal-treated bovine follicular fluid preparation with an arbitrary potency of $1 \mathrm{U} / \mu \mathrm{g}$ protein was used as a standard in the bioassay (Grootenhuis et al., 1989).

\section{Statistical analysis}

All data have been presented as means \pm SEM ( $n=3-4)$. The significances of differences between results of various treatments were assessed using Student's $t$-tests. Differences were considered significant if $P<0.05$ (two-tailed).

\section{Results}

\section{Developmental expression of inhibin subunit} $m R N A s$

As shown in Fig. $1 a$, the relative amounts of the $4.2 \mathrm{~kb}$ and $3.5 \mathrm{~kb} \beta$ B-subunit mRNAs (Toebosch et al., 1988) changed markedly during early postnatal testis development; a decrease of the $4.2 \mathrm{~kb}$ transcript was accompanied by an increase of the $3.5 \mathrm{~kb}$ species during the first 3 weeks of life. The total amount of $\beta$ B-subunit mRNA decreased after the age of 14 days (Fig. 1 ), and did not change further after 28 days of age. The amount of $1.6 \mathrm{~kb} \alpha$-subunit mRNA per mg total RNA was relatively constant until the age of 21 days, and decreased only slightly afterwards. Optical density of hybridizing bands was not normalized against the $\beta$-actin signal, since the testicular concentration of this mRNA also changes with age (Slaughter et al., 1987)

Distribution of inhibin subunit mRNAs in different fractions of sucrose gradients

In order to study whether both $\beta \mathrm{B}$-subunit mRNAs are actively translated, centrifugation of postnuclear supernatants through continuous sucrose gradients was performed. In this way, polysomes, monosomes, and ribonucleoprotein fractions can be separated. Fig. $2 a$ shows the $\mathrm{OD}_{260 \mathrm{~nm}}$ profiles of a gradient in which the polysomes are intact in the presence of $\mathrm{Mg}^{2+}$
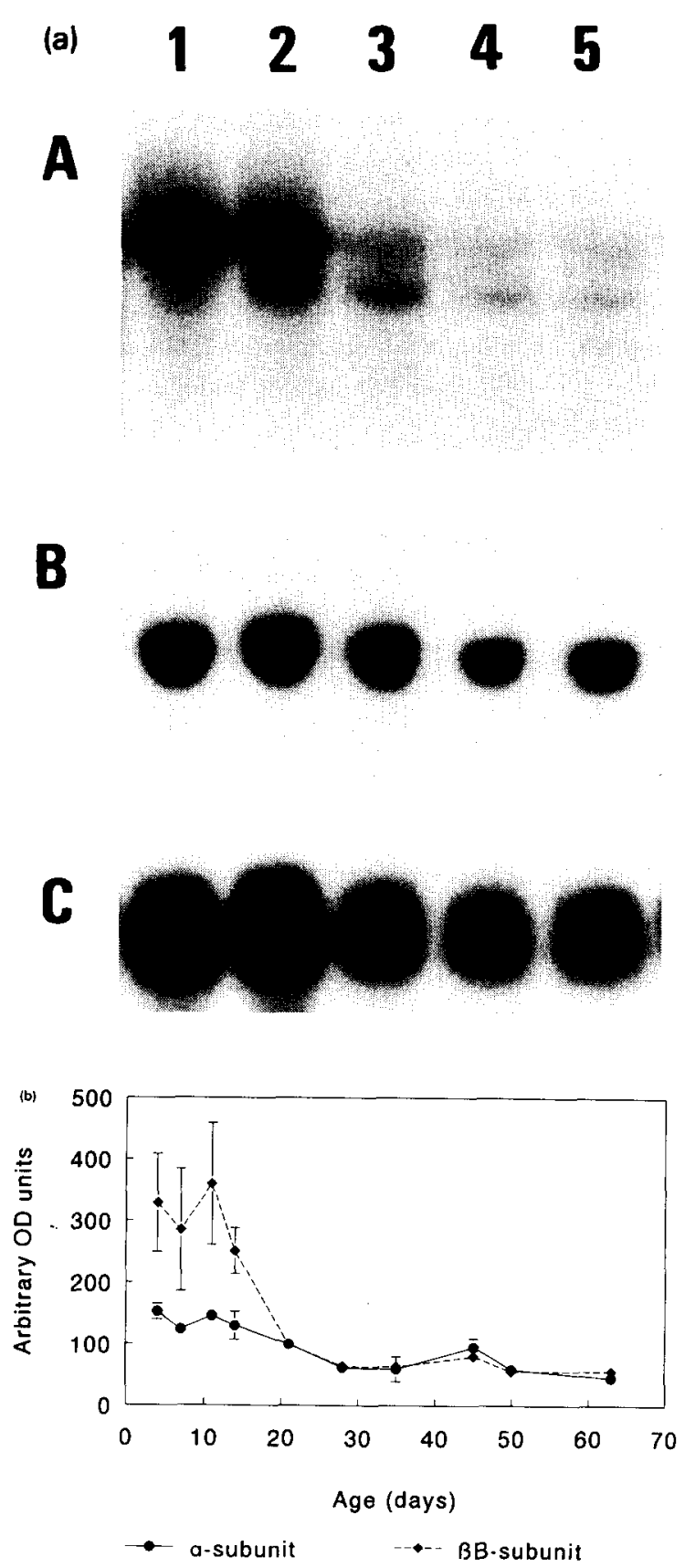

Fig. 1. (a) Expression of inhibin $\beta$ B-subunit (A), $\alpha$-subunit (B), and actin (C) mRNA in total RNA from testes of rats of different ages. Per lane, $40 \mu \mathrm{g}$ of total RNA was applied. Numbers above the lanes indicate the age of the rats in weeks. (b) Relative OD values (day $21-100$ ) of autoradiograms of Northern blots of testes from rats of various ages, hybridized with probes for the $\alpha$ - and $\beta$ B-subunit of inhibin. Values represent means \pm SEM of three RNA preparations, each extracted from pooled testes from 3-10 rats. 
(HKM), and of a gradient in which the transcripts were dissociated from the ribosomes by addition of EDTA (HKE). Equivalent percentages of each fraction were applied on gel, and ethidium bromide was used to confirm the intactness of RNA (not shown). Both $\beta$ B-subunit mRNAs and the $\alpha$-subunit mRNA were present in the polysomal fraction of the gradient containing $\mathrm{Mg}^{2+}$, and

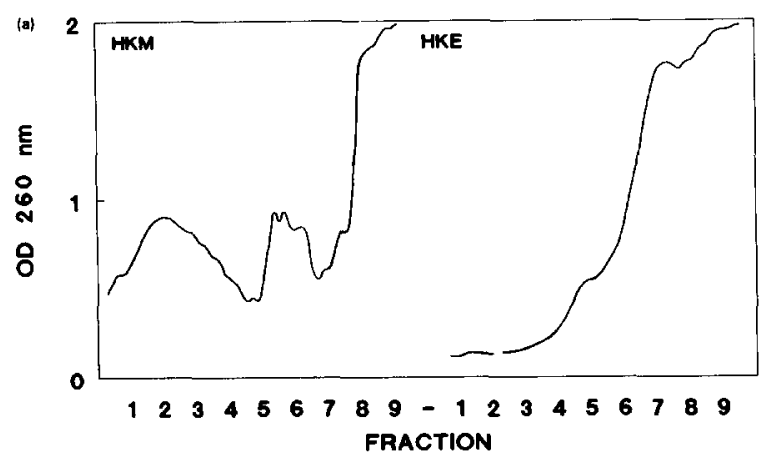

(b)

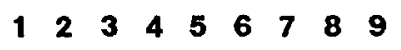

HKM

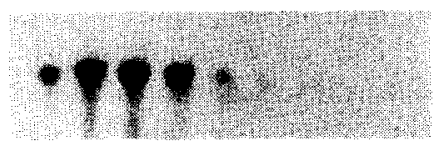

a-subunit

HKE

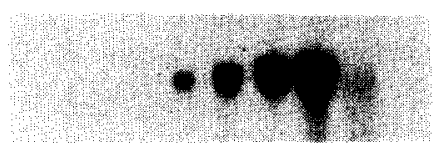

HKM

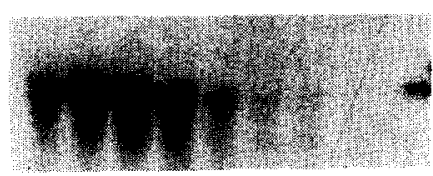

BB-subunit

HKE

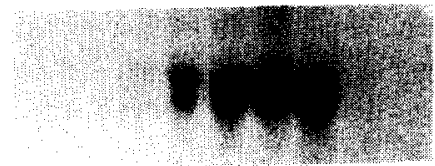

Fig. 2. (a) $\mathrm{OD}_{260 \mathrm{~nm}}$ profiles of sucrose gradients of testicular polysomes. Intact polysomes (HKM) and dissociated polysomes (HKE) were isolated from 21-day-old rat testes. Fractions have been numbered from bottom (left) to top (right). (b) Polysomal distribution of inhibin $\alpha$-subunit and $\beta B$-subunit mRNAs from rat testis. Fractions of sucrose gradients of polysomes were analyzed on Northern blot. could be detached from the ribosomes by addition of EDTA (Fig. $2 b$ ).
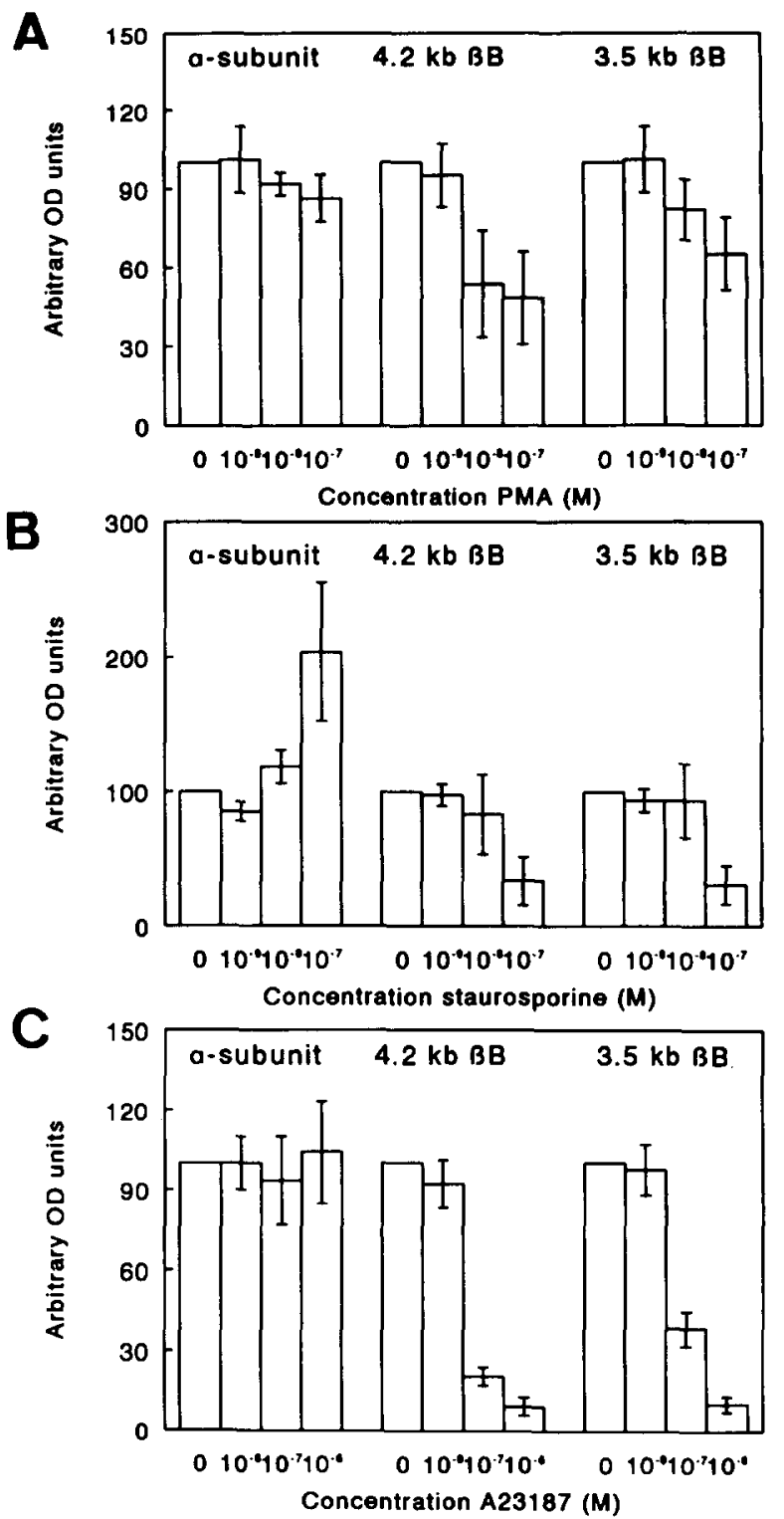

Fig. 3. Effect of PMA ( $A$ ), staurosporine $(B)$ and A23187 $(C)$ on inhibin $\alpha$ - and $\beta$ B-subunit mRNA expression in cultured Sertoli cells. Sertoli cells were incubated for $24 \mathrm{~h}$ in the presence of different concentrations of PMA or staurosporine. The inhibin subunit mRNA levels were assessed by Northern blot analysis, using $40 \mu \mathrm{g}$ of total RNA per lane. The inhibin subunit mRNA bands were scanned, and the resulting $O D$ values were expressed relative to the control value $(100 \%)$. Values represent means \pm SEM of 3-4 separate experiments. 
Effect of PMA and staurosporine on inhibin subunit $m R N A$ expression

A possible role of the protein kinase $C$ pathway in the regulation of the inhibin production was studied in cultured Sertoli cells, using the phorbol ester PMA, and the protein kinase $\mathrm{C}$ inhibitor staurosporine. After a $24 \mathrm{~h}$ preincubation period, the cells were incubated for $24 \mathrm{~h}$ in the presence of different concentrations of PMA or staurosporine. This incubation period was chosen, since some of the treatments suppressed the amount of inhibin bioactivity below the detection limit of the bioassay when cells were incubated for shorter time periods. As a control, the solvent of these agents, dimethyl sulfoxide (DMSO), was added. Fig. $3 A$ and $B$ shows the effects of PMA and staurosporine on the mRNA levels of the inhibin $\alpha$ - and $\beta$ B-subunit. PMA caused a dosedependent decrease of the amount of both $\beta B$ subunit mRNAs $\left(4.2 \mathrm{~kb}\right.$ mRNA: $10^{-8} \mathrm{M}, P<$ $0.05,10^{-7} \mathrm{M}, P<0.025 ; 3.5 \mathrm{~kb}$ mRNA: $10^{-7} \mathrm{M}$, $P<0.05$ ), whereas no effect on the $\alpha$-subunit mRNA level was found. Staurosporine at a concentration of $10^{-7} \mathrm{M}$ also caused a significant decrease of both $\beta$ B-subunit mRNAs $(4.2 \mathrm{~kb}$ mRNA $P<0.01,3.5 \mathrm{~kb}$ mRNA $P<0.005)$. At this concentration, the level of $\alpha$-subunit mRNA was significantly increased $(P<0.01)$.

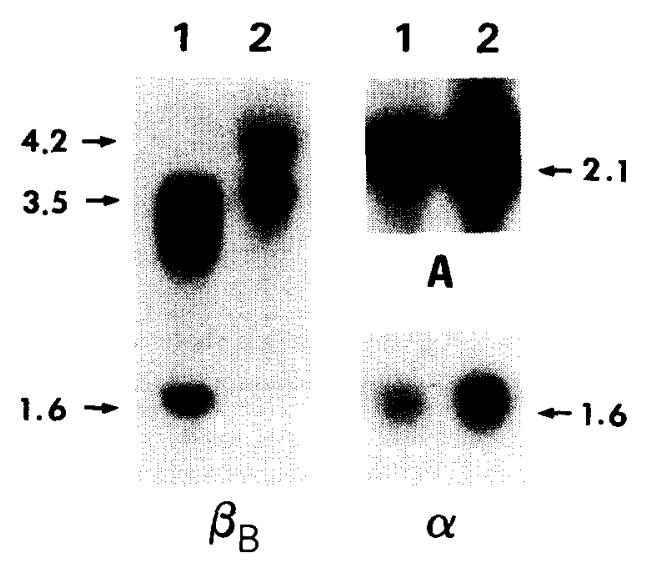

Fig. 4. Effect of $10^{-5} \mathrm{M}$ A23187 on inhibin $\alpha$ - and $\beta$ B-subunit mRNA expression in cultured Sertoli cells. The inhibin subunit ( $\beta B$ and $\alpha$ ) and actin (A) mRNA levels were assessed by Northern blot analysis. Lanes: $1,10^{-5} \mathrm{M} \mathrm{A23187;2,}$ control.

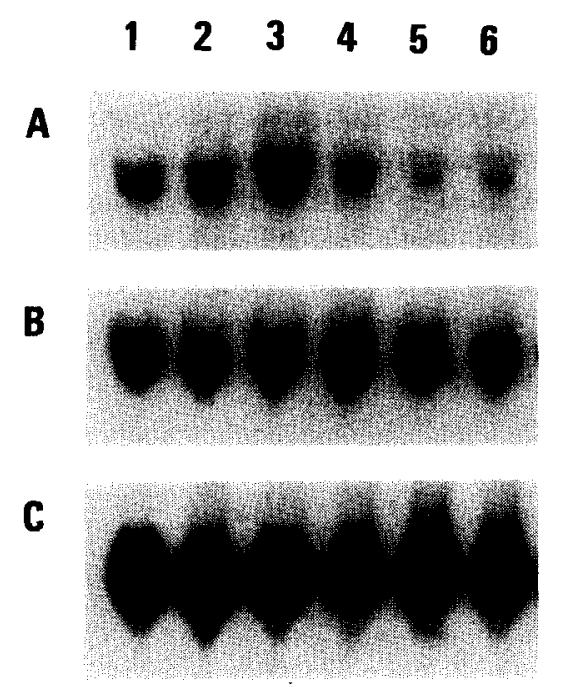

Fig. 5. Time-course of the effect of PMA on $(A)$ inhibin $\beta$ B-subunit, $(B)$ inhibin $\alpha$-subunit, and $(C)$ actin mRNA expression. Sertoli cells were cultured for different periods of time in the presence or absence of $10^{-7} \mathrm{M}$ PMA. The inhibin subunit mRNA levels were assessed by Northern analysis, using $40 \mu \mathrm{g}$ of total RNA per lane. Lanes: 1, control $0 \mathrm{~h} ; 2$, control 24 h; 3, PMA 2 h; 4, PMA 4 h; 5, PMA 8 h; 6, PMA 24 h.

Involvement of calcium in the regulation of the inhibin subunit $m R N A$ expression

The calcium ionophore A23187 was used to determine whether a rise in intracellular calcium can affect the inhibin subunit mRNAs. Sertoli cells were cultured for $24 \mathrm{~h}$ in the presence of various concentrations of A23187. A23187 at concentrations ranging from $10^{-8}$ to $10^{-6} \mathrm{M}$ caused a dose-dependent decrease of the $\beta \mathrm{B}$-subunit mRNAs (Fig. $3 C ; 10^{-7} \mathrm{M}$ and $10^{-6} \mathrm{M}, P<$ 0.0005 ). At $10^{-5} \mathrm{M} \mathrm{A23187}$, the expression of the $3.5 \mathrm{~kb} \beta \mathrm{B}$-subunit mRNA was dramatically elevated, whereas an additional smaller band hybridizing with the $\beta$ B-probe was found (Fig. 4), and expression of $\alpha$-subunit mRNA and actin was decreased. Furthermore, the morphology of the cells was altered at this concentration of A23187, and attachment to the flask was decreased.

Time course of the effect of PMA, staurosporine and $A 23187$ on the expression of $\beta B$-subunit mRNAs

Cells were cultured for different periods of time in the presence of $10^{-7} \mathrm{M}$ PMA, $10^{-7} \mathrm{M}$ 
staurosporine, or $10^{-7} \mathrm{M}$ A23187. The expression of the $\beta$ B-subunit mRNAs was initially increased after incubation with PMA for $2 \mathrm{~h}$ (Fig. 5 ), and thereafter decreased. Staurosporine had a similar effect on the $\beta B$-subunit mRNA expression, whereas the expression of the $\alpha$-subunit mRNA was gradually increased with time by staurosporine (not shown). A23187 caused a time-dependent decrease of the $\beta B$-subunit mRNAs, wherease the $\alpha$-subunit mRNA was not influenced (not shown).

Effect of PMA, staurosporine and A23187 on inhibin bioactivity and immunoactivity

Media from the cultures described above were concentrated and used for determination of inhibin bioactivity and immunoactivity. PMA, staurosporine and A23187 caused a decrease in the amount of bioactivity present in the media (Table 1). When the media of Sertoli cells cultured in the presence of PMA or A23187 were subjected to Western blotting with an antiserum against the $22 \mathrm{~N}$-terminal amino acid residues of the inhibin $\alpha$-subunit, an increased amount of a protein with a molecular weight of $26 \mathrm{kDa}$ was observed (Fig. 6), whereas the amount of the $32 \mathrm{kDa} \alpha \beta$-inhibin dimer was decreased. Development of a parallel blot with an antiserum against the pro-part of the

\section{TABLE 1}

INHIBIN BIOACTIVITY IN THE MEDIA OF SERTOLI CELLS CULTURED FOR $24 \mathrm{~h}$ IN THE PRESENCE OF DIFFERENT CONCENTRATIONS OF PMA, STAUROSPORINE OR A23187

Values represent means \pm SEM of three incubations.

\begin{tabular}{|c|c|}
\hline Addition & Bioactivity $(\mathrm{U} / \mathrm{ml})$ \\
\hline$\overline{\text { DMSO (control) }}$ & $21.1 \pm 0.8$ \\
\hline PMA $10^{-9} \mathrm{M}$ & $15.0 \pm 0.6^{\mathrm{a}}$ \\
\hline PMA $10^{-8} \mathbf{M}$ & $10.3 \pm 1.5^{\mathrm{a}}$ \\
\hline PMA $10^{-7} \mathrm{M}$ & $10.7 \pm 2.7^{c}$ \\
\hline Staurosporine $10^{-9} \mathrm{M}$ & $17.0 \pm 0.6^{b}$ \\
\hline Staurosporine $10^{-8} \mathrm{M}$ & $13.0 \pm 2.1^{\mathrm{c}}$ \\
\hline Staurosporine $10^{-7} \mathrm{M}$ & $15.6 \pm 2.2^{d}$ \\
\hline A23187 $10^{-8} \mathrm{M}$ & $3.0 \pm 3.0^{\mathrm{a}}$ \\
\hline A23187 $10^{-7} \mathrm{M}$ & $2.7 \pm 1.5^{\mathrm{a}}$ \\
\hline A23187 $10^{-6} \mathrm{M}$ & $2.2 \pm 2.0^{a}$ \\
\hline
\end{tabular}

${ }^{\mathrm{a}} p<0.005 ;{ }^{\mathrm{b}} p<0.01 ;{ }^{\mathrm{c}} p<0.025 ;{ }^{\mathrm{d}} p<0.05$.

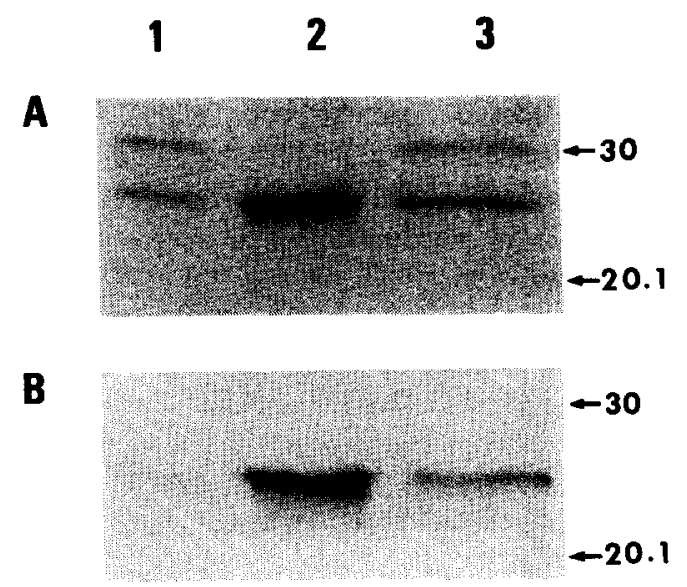

Fig. 6. Effect of PMA and A23187 on inhibin $\alpha$-subunit containing proteins detected by Western blotting. Sertoli cells were cultured for $24 \mathrm{~h}$. $(A)$ Western blot of proteins detected with an antiserum directed against the $\alpha \mathrm{C}$-part of inhibin. ( $B$ ) Western blot of proteins detected with an antiserum directed against the pro-part of the inhibin $\alpha$-subunit. Lanes: 1 , control; 2, A21387 $\left(10^{-7} \mathrm{M}\right) ; 3$, PMA $\left(10^{-7} \mathrm{M}\right)$.

$\alpha$-subunit indicated an increase of the same 26 kDa moiety.

\section{Discussion}

The most striking change in the amounts of inhibin subunit mRNAs which occurs during postnatal testis development is a change in the ratio of the two $\beta B$-subunit mRNAs. Other studies did not detect this changed ratio, since a different technique was used (S1-nuclease protection; Meunier et al., 1988), or testes of older animals were analyzed (Feng et al., 1989a). A good correlation was found when the total of both $\beta$ B-subunit mRNA levels was compared with the production of bioactive inhibin by cultured Sertoli cells (Ultee-van Gessel et al., 1987). Changes of $\alpha$-subunit mRNA expression at the various ages were in agreement with the observations of Meunier et al. (1988) and Keinan et al. (1988), and are correlated with the amount of immunoreactive inhibin found in testes of rats of various ages (Rivier et al., 1988). The interpretation of the data is complicated by the fact that Leydig cells also express inhibin $\alpha$-subunit mRNA (Risbridger et al., 1989a; de Winter et al., 1992). However, the contribution of these cells to the 
intratesticular level of $\alpha$-subunit mRNA seems relatively small (de Winter et al., 1992). Furthermore, Maddocks and Sharpe (1989) suggested that the production of inhibin by Leydig cells in vivo is negligible, and de Winter et al. (1992) could not show production of bioactive inhibin by Leydig cells.

It remains unclear which factor causes the switch to a smaller $\beta$ B-subunit mRNA with increasing age. Also the functional significance of the occurrence of the two $\beta \mathrm{B}$ mRNAs which are both actively translated on ribosomes (Fig. $2 b$ ) remains unknown. These RNAs could differ in polyadenylation, but it is also possible that they code for different proteins. The genomic organization of the rat $\beta B$-subunit gene shows the presence of a $3 \mathrm{~kb}$ intron in the $5^{\prime}$ end of the coding region (Feng et al., 1989b). Since the $\beta B$ cDNA probe used herein only contains approximately 60 bases which are located in the first exon, and more than $1.4 \mathrm{~kb}$ located in the second exon, it is possible that this probe hybridizes with mRNAs originating from two different first exons, spliced to the same second exon. Such mRNAs would code for different proteins, as also has been demonstrated for transforming growth factor (TGF) $\beta 1$, which is another member of the TGF $\beta$ family (Kondaiah et al., 1988).

Prolonged stimulation of protein kinase $\mathrm{C}$ by PMA suppresses $\beta B$-subunit mRNA expression, after an initial increase. Most likely, the suppressive effect after $24 \mathrm{~h}$ is caused by an inhibition of protein kinase $\mathrm{C}$, since long-term stimulation with PMA leads to a downregulation of this kinase (Hepler et al., 1988, and review by Nishizuka, 1988). This also explains why the protein kinase $C$ inhibitor staurosporine had similar effects on the $\beta B$-subunit mRNA expression after $24 \mathrm{~h}$, as compared to the effect of PMA. However, the reason for the initial stimulation of $\beta B$-subunit mRNA expression by staurosporine is not clear, since staurosporine interacts with the catalytic moiety of protein kinase C (Nakadate et al., 1988; Wolf and Bagglioni, 1988). The increased $\alpha$-subunit mRNA expression at $10^{-7} \mathrm{M}$ staurosporine could be explained by the fact that staurosporine at higher doses also affects other protein kinases (Rüegg and Burgess, 1989). Finally, addition of the $\mathrm{Ca}^{2+}$-ionophore $\mathrm{A} 23187$ also suppressed the expression of the $\beta$ B-subunit mRNAs. Although protein kinase $\mathrm{C}$ and $\mathrm{Ca}^{2+}$ mobilization are generally synergistic, not all protein kinase $\mathrm{C}$ subspecies are calcium-dependent (review, see Nishizuka, 1988), and hormones can affect intracellular calcium levels without affecting protein kinase C (review, see Nemere and Norman, 1991). This could explain the diverging short-term effects of PMA and A23187 on the $\beta$ B-subunit mRNA expression. Although $10^{-5} \mathrm{M}$ A23187 has been used in other studies, we think data using this dose of A23187 should be interpreted with caution in view of our findings of a diverging size of $\beta \mathrm{B}$-subunit mRNA and an altered morphology of the cells.

A decreased $\beta B$-subunit mRNA expression was always accompanied by a decrease in bioactive inhibin. However, there was no direct correlation between the decrease of $\beta$ B-subunit expression and bioactivity, indicating that effects at the translational level may also play a role in the suppression of bioactivity. Alternatively, differences might be explained on basis of the fact that the bioactivity in the media results from a $24 \mathrm{~h}$ accumulation process, whereas mRNA levels only reflect the situation at the end of this period. The decreased bioactivity in the media paralleled the increase at the amount of $26 \mathrm{kDa}$ immunoreactivity detected on Western blot using antibodies against the C-terminal and pro-regions of the inhibin $\alpha$-subunit. This indicates that the $26 \mathrm{kDa}$ entity consists of an $\alpha \mathrm{C}$ molecule linked to the pro-region of the $\alpha$-subunit of inhibin (pro- $\alpha \mathrm{C}$ ). The pro- $\alpha \mathrm{C}$ molecule has been isolated from follicular fluid by Sugino et al. (1989) and Robertson et al. (1989), and has been shown to be produced by Sertoli cells (de Winter et al., 1992).

The increased production of pro- $\alpha \mathrm{C}$ after decreased expression of $\beta \mathrm{B}$-subunit mRNA suggests that the $\beta \mathrm{B}$-subunit is a limiting factor in the production of bioactive inhibin. Since the pro- $\alpha \mathrm{C}$ molecule is 2.9 -fold more immunoreactive with the antibodies against the $\alpha$-chain of inhibin than the intact inhibin molecule (Robertson et al., 1989) and a decreased production of bioactive inhibin is accompanied by an increased production of pro- $\alpha \mathrm{C}$, our results are in contrast with observations of Gonzales et al. (1989a, b), who found a decreased inhibin immunoreactivity after 
treatment with PMA of cultured adult rat seminiferous tubules. A possible explanation for this discrepancy could be that cultured tubules of mature rats show less downregulation of protein kinase $\mathrm{C}$ by PMA than immature Sertoli cells.

The question remains which physiological factor is responsible for the regulation of $\beta \mathrm{B}$-subunit mRNA expression in Sertoli cells. Interestingly, in cultured rat granulosa cells, FSH not only increases the expression of the $\alpha$ - and $\beta$ Asubunit mRNAs, but also the expression of $\beta \mathrm{B}$ subunit mRNAs (Turner et al., 1989). In these granulosa cells, only the $4.2 \mathrm{kB} \beta \mathrm{B}$-subunit mRNA is present. This suggests that in those cells also the protein kinase C pathway is affected by FSH. Indeed, Pennybacker and Herman (1991) have shown that FSH influences c-fos mRNA expression in granulosa cells via protein kinase $\mathrm{C}$.

In conclusion, we have shown that the expression of the $\beta B$-subunit mRNAs is differentially regulated in vivo. Furthermore, our results indicate that both $\beta$ B-subunit mRNAs are actively translated. Finally a decreased expression of $\beta \mathrm{B}$ subunit mRNAs in cultured Sertoli cells leads to a decreased production of bioactive inhibin, and an increased production of a molecule which appears to be a combination of the pro- and C-terminal parts of the inhibin $\alpha$-subunit.

\section{Acknowledgements}

This work was supported financially by the Dutch Science Foundation (N.W.O.) through GB-MW (Medical Sciences). We would like to thank Dr. S. Shimasaki, and Dr. N. Ling for their generous gift of the inhibin cDNA probes, and the NIADDK for the materials used for the estimation of FSH in the inhibin bioassay.

\section{References}

Bicsak, T.A., Vale, W., Vaughan, J., Tucker, E.M., Cappel, S. and Hsueh, A.J.W. (1987) Mol. Cell. Endocrinol. 49, 211 217.

Chomczynski, P. and Sacchi, N. (1987) Analyt. Biochem. 162, 156-159.

De Winter, J.P., Timmerman, M.A., Vanderstichele, H.M.J., Klaij, I.A., Grootenhuis, A.J., Rommerts, F.F.G. and de Jong, F.H. (1992) Mol. Cell. Endocrinol. 83, 105-115.
Esch, F.S., Shimasaki, S., Cooksey, K., Mercado, M., Mason, A.J., Ying, S.-Y., Ueno, N. and Ling, N. (1987) Mol. Endocrinol. 1, 388-396.

Feinberg, A.P. and Vogelstein, B. (1983) Anal. Biochem. 132, 6-13.

Feng, Z.-M., Bardin, C.W. and Chen, C.-L.C. (1989a) Mol. Endocrinol. 3, 939-948.

Feng, Z.-M., Li, Y.-P. and Chen, C.-L.C. (1989b) Mol. Endocrinol. 3, 1914-1925.

Galdieri, M., Ziparo, E., Palombi, F., Russo, M.A. and Stefanini, M. (1981) J. Androl. 2, 249-254.

Gonzales, G.F., Risbridger, G.P. and de Kretser, D.M. (1989a) Mol. Cell. Endocrinol. 61, 209-216.

Gonzales, G.F., Risbridger, G.P. and de Kretser, D.M. (1989b) J. Endocrinol. 123, 213-219.

Grootenhuis, A.J., Steenbergen, J., Timmerman, M.A., Dorsman, A.N.R.D., Schaaper, W.M., Meloen, R.H. and de Jong, F.H. (1989) J. Endocrinol. 122, 293-301.

Grootenhuis, A.J., van Beurden, W.M.O., Timmerman, M.A. and de Jong, F.H. (1990) Mol. Cell. Endocrinol. 74, 125132.

Handelsman, D.J., Spaliviero, J.A., Kidston, E. and Robertson, D.M. (1989) Endocrinology 125, 721-729.

Hepler, J.R., Earp, H.S. and Harden, T.K. (1987) J. Biol. Chem. 263(16), 7610-7619.

Keinan, D., Madigan, M.B., Bardin, C.W. and Chen, C.-L.C. (1989) Mol. Endocrinol. 3, 29-35.

Kew, D., Jin, D.F., Kim, F., Laddis, T. and Kilpatrick, D.L. (1989) Mol. Endocrinol. 3, 1191-1196.

Klaij, I.A., Toebosch, A.M.W., Themmen, A.P.N., Shimasaki, S., de Jong, F.H. and Grootegoed, J.A. (1990) Mol. Cell. Endocrinol. 68, 45-52.

Kondaiah, P., van Obberghen-Schilling, E., Ludwig, R.L., Dhar, R., Sporn, M.B. and Roberts, A.B. (1988) J. Biol. Chem. 263, 18313-18317.

Krummen, L.A., Toppari, J., Kim, W.H., Morelos, B.S., Ahmad, N., Swerdloff, R.S., Ling, N., Shimasaki, S., Esch, F. and Bhasin, S. (1989) Endocrinology 125, 1630-1637.

Laemmli, U.K. (1970) Nature 227, 680-685.

Maddocks, S. and Sharpe, R.M. (1989) Mol. Cell. Endocrinol. 67, 113-118.

Meunier, H., Rivier, C., Evans, R.M. and Vale, W.W. (1988) Proc. Natl. Acad. Sci. USA 85, 247-251.

Monaco, L. and Conti, M. (1987) Mol. Cell. Endocrinol. 49, 227-236.

Nakadate, T., Jeng, A.J. and Blumberg, P.M. (1988) Biochem. Pharmacol. 37, 1541-1545.

Nemere, I. and Norman, A.W. (1991) Mol. Cell. Endocrinol. 80, C165-C169.

Nishizuka, Y. (1988) Nature 334, 661-665.

Pennybacker, M. and Herman, B. (1991) Mol. Cell. Endocrinol. 80, 11-20.

Risbridger, G.P., Clements, J., Robertson, D.M., Drummond, A.E., Muir, J., Burger, H.G. and de Kretser, D.M. (1989a) Mol. Cell. Endocrinol. 66, 119-122.

Risbridger, G.P., Hancock, A., Robertson, D.M., Hodgson, Y. and de Kretser, D.M. (1989b) Mol. Cell. Endocrinol. 67, $1-9$. 
Rivier, C., Cajander, S., Vaughan, J., Hsueh, A.J.W. and Vale, W. (1988) Endocrinology 123, 120-126.

Robertson, D.M., Giacometti, M., Foulds, L.M., Lahnstein, J., Goss, N.H., Hearn, M.T.W. and de Kretser, D.M. (1989) Endocrinology 125, 2142-2149.

Rüegg, U.T. and Burgess, G.M. (1989) Trends Pharmacol. Sci. $10,218-220$.

Slaughter, G.R., Needleman, D.S. and Means, A.R. (1987) Biol. Reprod. 37, 1259-1270.

Sugino, K., Nakamura, T., Takio, K., Titani, K., Miyamoto, K., Hasegawa, Y., Igarashi, M. and Sugino, H. (1989) Biochem. Biophys. Res. Commun. 159, 1323-1329.

Themmen, A.P.N., Blok, L.J., Post, M., Baarends, W.M., Hoogerbrugge, J.W., Parmentier, M., Vassart, G. and Grootegoed, J.A. (1991) Mol. Cell. Endocrinol. 78, R7R13.
Toebosch, A.M.W., Robertson, D.M., Trapman, J., Klaassen, P., de Paus, R.A., de Jong, F.H. and Grootegoed, J.A. (1988) Mol. Cell. Endocrinol. 55, 101-105.

Turner, I.M., Saunders, P.T.K., Shimasaki, S. and Hillier, S.G. (1989) Endocrinology 125, 2790-2792.

Ultee-van Gessel, A.M. and de Jong, F.H. (1987) J. Endocrinol. 113, 103-110.

Van Laar, J.H., Voorhorst-Ogink, M.M., Zegers, N.D., Boersma, W.J.A., Claassen, E., van der Korput, J.A.G.M., Ruizeveld de Winter, J.A., van der Kwast, Th.H., Mulder, E., Trapman, J. and Brinkmann, A.O. (1989) Mol. Cell. Endocrinol. 67, 29-38.

Wolf, M. and Bagglioni, M. (1988) Biochem. Biophys. Res. Commun. 154, 1273-1279. 